\title{
We moeten innovatief blijven
}

\author{
Prof. dr. Peter F.A. Mulders
}

Het is alsof er niets aan de hand is: het abstractnummer van het Tijdschrift voor Urologie voor de najaarsvergadering 2020 ligt op uw deurmat. Recent heeft de wetenschappelijke commissie van de NVU de abstract selectievergadering gehad. Digitaal, dat wel. Deze abstracts zijn geselecteerd na individueel scoren en bij discrepantie een 'levendige' digitale discussie. Moet wel anders zijn geweest. Maar ze zijn eruit gekomen en hebben een zeer gevarieerd wetenschappelijk programma kunnen samenstellen met de publicatie van de abstracts in dit nummer als hoogtepunt.

Op het moment dat ik dit schrijf, gaat de najaarsvergadering fysiek door, kunt $\mathrm{u}$ dit tijdschrift meenemen en aanwezig zijn tijdens de presentaties. Dat is mooi, omdat de vergadering de basis is voor een goede wetenschappelijke discussie over urologische onderwerpen die ons allen aangaan. Ook geeft de vergadering inzicht in wat we in deze periode nog allemaal kunnen doen op onderzoeksgebied, wie daar nog mee bezig kunnen zijn.

De impact van alle veranderingen van de afgelopen tijd zal enorm zijn en we zullen innovatief moeten zijn om ons vak constant te blijven verbeteren. Dit abstractnum-

mer helpt daarbij, zeker als we elkaar fysiek (op 1,5 meter) kunnen treffen. Ik verwacht dat als de vergadering doorgaat, de opkomst groot zal zijn. De behoefte is groot. Tot in Nieuwegein!

NB. Ik heb het 'hoge woord' dit keer niet gebruikt.

\section{Addendum}

Helaas is het mij toch niet gelukt om het woord Corona te vermijden. Opnieuw maakt het virus een aanpassing noodzakelijk. Ondanks dat ik hierboven aankondigde dat we weer fysiek zouden kunnen vergaderen, heeft er een noodzakelijke aanpassing plaatsgevonden. Het bestuur van de NVU heeft moeten besluiten om de najaarsverdadering niet meer fysiek te doen (we konden maar met zeer weinigen in Nieuwegein aanwezig zijn). Wel zullen de abstracts gepresenteerd worden en dus bent $u$ nog steeds in de gelegenheid om hierop te reageren. Het is een hoop geregel en we zijn benieuwd hoe de Nederlandse wetenschap zijn voortgang krijgt.

Tot digitaal (helaas)

Peter F.A. Mulders - uroloog 